\title{
Exploring Mobile Banking in the Humanistic Financial Inclusion of Visually Impaired People in Zimbabwe
}

\author{
Dr Kudakwashe Zvitambo Ropafadzo Mhizha \\ Reformed Church University, Zimbabwe
}

\begin{abstract}
Humanistic financial inclusion provides a leeway to improve the standard of living of the underprivileged in society, inclusive of the visually impaired people. In order to fulfil its mandate of promoting economic development through availing financial products and services to all, the financial sector has to support and provide assistive devices which promote humanistic financial inclusion of visually impaired people. The focus of this paper was to explore mobile banking in the humanistic financial inclusion of visually impaired people in Zimbabwe using a selected rural district as a case study. The objectives of the study were to assess the awareness of visual impaired people to humanistic financial inclusion via mobile banking; to evaluate the affordability of assistive mobile devices which promote humanistic financial inclusion; to establish the literacy of visual impaired people as a means of promoting humanistic financial inclusion; and to examine the accessibility of visually impaired people to mobile banking as way of improving humanistic financial inclusion. The study used qualitative approach which advocates interviews and observations as data collection methods. Data was gathered from 20 interviewed and 30 observed visually impaired participants. The data indicated that visually impaired people were financially excluded and living pathetic lives. The study recommends that government, Non-Profit Organisations and corporate world should make a deliberate effort to make sure that humanistic financial inclusion is implemented to people living with visual impairment in rural areas.
\end{abstract}

Keywords: Humanistic financial inclusion; Mobile banking; visual impairment

DOI: $10.7176 / \mathrm{EJBM} / 11-3-10$

\section{INTRODUCTION}

Global reports (see Global Financial development report, 2014) reveal that about 50 percent of adults are financially excluded. The reports do not highlight the percentage of people with visual impairment financially included. The absence of information on disadvantaged or vulnerable groups who are financial included paint a bad picture on the livelihood of these groups. A study done by Bhuvana and Vasuntha (2016) in India emphasise the importance of financial inclusion. According to the United Nations, there are a plethora of financial inclusion goals (see, Sharma \& Kukreja, 2013:16) which need to be fulfilled by a nation to improve the standard of living of its citizens.

Technologies, like mobile banking and biometric capturing of data, are among the factors which may improve the humanistic financial inclusion of people in the developing nations (Conference Report, 2016). International studies done by several scholars (see Morgan \& Pontine, 2014; Maturuka, 2015; Bhuvana \& Vasuntha, 2016) testify the significance of mobile banking to humanistic financial inclusion. However, these researches do not give insight into the state of affairs of financial inclusion of disadvantaged groups like visually impaired people.

In Zimbabwe, scholars analysed the impact of financial inclusion on people (see Ndlovu \& Ndlovu, 2013; Mago \& Chitokwindo, 2014; Chinakidzwa, Mbengo \& Nyatsambo, 2015). However, these studies do not shade light on the humanistic financial inclusion of visually impaired people. These studies emphasise economistic view of financial inclusion which benefits the shareholders who want to expand their market share.

This paper aims to exploring mobile banking in the humanistic financial inclusion of visually impaired people in Zimbabwe using Chivi District as a case study. The objectives of the study were to assess the awareness of visual impaired people to humanistic financial inclusion via mobile banking; to evaluate the affordability of assistive mobile devices which promote humanistic financial inclusion; to establish the literacy of visual impaired people as a means of promoting humanistic financial inclusion; and to examine the accessibility of visually impaired people to mobile banking as way of improving humanistic financial inclusion. The paper begins by reviewing literature on humanistic financial inclusion and mobile banking. It further presents the research methodology used in gathering data followed by the results and discussions. As a way of contributing to new knowledge, the paper concludes the arguments from the results then suggests possible recommendations and areas for further study.

\section{LITERATURE REVIEW}

Humanistic Financial Inclusion

Humanistic view has become of interest to scholars as opposed to economistic view (see Zvitambo, 2017). Although financial inclusion has received attention from scholars, there is scarce literature on humanistic 
financial inclusion. This section analyses the narrative of humanistic financial inclusion in the context of improving the livelihood of people.

Humanistic financial inclusion is a phrase comprising of three words, namely "humanistic", "finance" and "inclusion". Humanistic, according to humanists, refer to the fair treatment of human being in any set-up. Human beings need to be treated with respect and dignity. Kant argues that human beings should not be means to an end. That means human beings should not be used for economic gain without them benefiting from the transactions. Finance refers to the day-to-day activities which have to do with money. Inclusion means involvement or participation of human beings in certain activities and transactions. However, humanistic financial inclusion can be defined and analysed from various scholars' perspectives.

Many scholars defined financial inclusion, but the definition of humanistic financial inclusion is scare. Sharme and Kukreja (2013) posit that financial inclusion refers to the delivery of financial services, at affordable costs, to sections of disadvantaged and low income groups of society. This definition emphasise the action of delivery but do not indicate who deliver (is it government or corporate community) the service to the vulnerable groups. This creates a sense of anticipation by the disadvantaged groups without knowing who will deliver the service.

Similarly, Morgan and Pontines (2014) postulate that financial inclusion can be described as a process of ensuring access to financial services and timely and adequate credit where needed by vulnerable groups such as weaker sections and low income groups at an affordable costs. They argue that it represents access to a bank account backed by deposit, insurance and access to affordable credit and the payment system. This definition is based on many assumptions. Firstly, it assumes that financial excluded people have money. Secondly, they can borrow and be able to pay back. Thirdly, every person need to be insured, however, if one cannot pay insurance premium then how can you be insured. Lastly, it assumes that every person has a source of income, hence have money to bank. These assumptions do not hold water in developing countries like Zimbabwe where unemployment rate is estimated to be around 95 percent.

Financial inclusion, according to Global Financial development Report (2014) and supported by Mataruka (2015), is the proportion of individuals and firms that use financial services. This is an economistic view supported by individualism philosophy. It does not highlight the kind of individuals and firms financially included or shade light on those financially excluded, therefore, do not care who is included or not.

After analysing financial inclusion definitions by various scholars, this paper suggests the definition of humanistic financial inclusion. Humanistic financial inclusion refers to the respectful and dignified participation of human beings in the financial activities and transactions for the betterment of their welfare. Humanistic financial inclusion should be championed by the government as its social objective. The corporate world should also support it as their social responsibility by giving back to the society through activities that promote humanistic financial inclusion of disadvantaged groups, such as visually impaired people. This can also be achieved if banks make an effort to afford the vulnerable groups opportunities to take part in financial benefiting transactions. This definition leads to the review of literature presented by scholars on humanistic financial inclusion.

International Finance Corporation (2016), in its report, emphasised the benefits of financial inclusion, which may be regarded as humanistic financial inclusion. Humanistic financial inclusion creates opportunities for the disadvantaged members of society to take an active role in the economic activities thereby improving their standard of living. A productive community propels the economic growth of its country. Shah and Dubhashi (2015) point many benefits of financial inclusion which includes, create conditions for sustainable equitable growth, protect the disadvantaged from the clutches of unscrupulous money lenders, and create an avenue for poor people to participate in the economic activities of their country. Although many scholars agree that humanistic financial inclusion has many benefits, little research has been done on establishing the benefits of various modes of implementing humanistic financial inclusion, especially in developing countries like Zimbabwe.

Studies done in Zimbabwe on financial inclusion do not refer to humanistic financial inclusion but heavily rely on the business model of financial inclusion (see Ndlovu \& Ndlovu, 2013; Mago \& Chitokwindo, 2014; Mataruka, 2015). The depressed economic status of Zimbabwe creates a challenge on its model of humanistic financial inclusion. Most of the companies are retrenching and struggling to survive hence does not have the ability to sustainably implement humanistic financial inclusion or support it. The unemployment rate is estimated to be around 95 percent, meaning the majority of the people are facing a plethora of barriers to financial inclusion. The introduction of mobile banking was a way of solving cash crisis and not a form of humanistic financial inclusion. The study done by Mago and Chitokwindo (2014) reveals that people in the rural areas welcome the introduction of mobile banking, but it does not highlight the challenges being faced by Zimbabwean rural people in endeavouring to transact using mobile banking. The introduction of mobile banking in Zimbabwe has created more challenges than benefits for the disadvantaged people.

Mobile banking for people who are Visual Impaired 
Banks in developed countries have incorporated devices which assist visually impaired people (see Llyods bank Report, 2016). This had gone a long way in financially including the visually impaired people and making their standard of living better. Other countries like United States of American have instituted regulations which govern how banks should transact with visually impaired people (See American with Disabilities Act, ADA). A study done in India, using mixed method approach reveals that mobile banking improves humanistic financial inclusion of visually impaired people (Poisios, 2012; Ahmed, 2015; Pal, et al., 2017). On the other hand, the same study highlighted the challenges of mobile banking as cost factors, illiteracy among visually impaired people and accessibility of technology assistance devices.

Other studies concentrated on the services in the bank hall (Omari \& Zachary, 2013). In Africa, literature indicates that visual impaired people do not have access to technological devices like cell-phones. This cause security gaps because visually impaired people have to rely on other people when transacting. Navasimhan et al. (2012) indicate that the devices exists which can assist visually impaired people to transact without other people's help. However, they do not indicate the cost and availability of these devices in Africa (Munday, 2013).

In Zimbabwe, literature on the mobile banking for people with visual impairment is scarce. Study done concentrate on the mobile banking as a form of financial inclusion in general (Mago \& Chitokwindo, 2014). The Reserve bank of Zimbabwe (2017) guideline for customer protection does not indicate how people with visual impairment should be treated. The framework does not also address the issue of humanistic financial inclusion using mobile banking. A study done by Munemo (2015) reveals that 15 percent of the world population live with disability, 20 percent of the world's poorest people were people with disabilities and 90 percent of children with disabilities in developing countries do not attend school. The study also indicates that the literacy rate for adults with disabilities stood at 30 percent. This indicate that even the devices are availed some of the visually impaired people cannot access them. Most visually impaired people in Zimbabwe are reduced to beggars who roam the streets (Muromo, 2014). The state of affairs of people living in Zimbabwean rural areas have never been verified as far as humanistic financial inclusion using mobile banking is concerned. Other countries like South Africa have endeavoured to provide grants which cushion people with visual impairment to be humanistically financial included.

\section{METHODOLOGY}

The study was guided by an interpretive paradigm which posits that reality consists of human subjective experiences of the outside world; therefore, an inter-subjective epistemological and ontological belief of socially constructed reality can be implemented (Senevirane, 2013; Sefotho, 2015). Interpretive paradigm advocates qualitative approach which explores and comprehends the meaning individual or groups assign to social or human problem (Qu \& Dumay, 2011). The study used face-to-face interviews and observations as recommended by the qualitative approach.

The population and location of visually impaired people in the selected district could not be established from any source; hence, the study used snowballing non-probability sampling method to come out with a sample. The community and visually impaired people provided information on where to get visually impaired people. The researcher explained their rights and asked for their consent before involving them in the study.

The researcher interviewed 20 and also observed 30 visually impaired participants in the District. Face-toface interviews served to inquire the experiences of participants in mobile banking as a form of humanistic financial inclusion. Visually impaired people were interviewed at their homes. They were also observed to see how they transact in their day-to-day lives. The researcher spent accumulated time of 6 months observing these participants.

\section{RESULTS AND DISCUSSION}

Visually impaired people were more than willing to participate in the study. Most of the people approached were happy to provide information. The results are as follows:

\section{Awareness of Visually impaired people to mobile banking services}

Twenty visually impaired people interviewed accepted that they had heard of the availability of mobile banking services. They showed willingness to use it as revealed by other studies carried somewhere (Mago \& Chitokwindo, 2014). However, they did not understand how they could benefit from mobile banking. Further probing revealed that they only heard from sighted people speaking about mobile banking. Observations indicated that visually impaired people do not use mobile banking at all but rely on other people when transacting. This posed security challenges as people took advantage of them.

\section{Literacy of Visually impaired people}

Sixty percent of the interviewed visually impaired people revealed that they were illiterate. They indicated that the schools surrounding their villages could not offer services and teaching aids that accommodate them. Most of them grew up before the era when inclusive education was advocated for in Zimbabwe. Only a few lucky ones attended special schools which educated them but could only accommodate a limited number since they were 
donor funded and with limited facilities.

\section{Affordability of assistive mobile devices which promote humanistic financial inclusion to visually impaired people}

Eighty percent of the interviewed visually impaired people could not afford to purchase a cell-phone, let alone a smart-phone. They had never heard of a cell-phone with assistive devices which can help them to transact without help from third parties. This vindicates Munemo's (2015) assertion that most of the visually impaired people in developing countries are very poor. These visually impaired people were surviving with two meals a day which is below the United Nation recommendations. Therefore, buying a cell-phone was a luxury they could not afford. Ninety percent could not remember when they last received grants from Government of Zimbabwe. The researcher observed that these visually impaired people made use of neighbours to make calls to their relatives in times of crisis. Most of them could not merely read using Braille, hence having an assistive device with Braille was of no use.

\section{Accessibility of mobile banking services to visually impaired people}

Ten percent of the visually impaired people who had cell phones and relatives who regularly send them money revealed that they were not accessible to mobile banking services. They also indicated that due to insecurity, they had no choice but to visit banks to get their money. These expressed their displeasure of the unfriendliness of Zimbabwean banks to them. They could only access their money through the help of third parties. This is in contrast with other developed countries like Britain and America where visually impaired people make use of assistive devices when transacting with banks (Llyods Bank Report, 2016; Pal, et al., 2017). Personal observation showed that the area under study was associated with mobile network challenges that it was difficult to access banking services. People surrounding the area had to travel to certain areas to access mobile services. The study disclosed that visually impaired people welcome humanistic financial inclusion through mobile banking. However, they were of the view that government and the corporate world should play a significant role in making it a reality. The observation revealed that visually impaired people, if humanistically financial included, their standard of living will improve.

\section{CONCLUSION}

The study reveals that visually impaired people can embrace mobile banking as a means of humanistic financial inclusion. The study, therefore, recommends that all stakeholders' of the marginalised in society, the government included should carry out humanistic financial inclusion awareness campaigns in rural areas targeting people living with disabilities.

Illiteracy rate of visually impaired people in rural areas showed to be high. This may hinder their ability to accommodate mobile banking as a means of humanistic financial inclusion. Institutions of learning should carry out learning programmes in rural areas as their social responsibilities, especially, institutions of higher learning offering Special Needs programmes.

Accessibility to banking showed to be a nightmare to visually impaired people living in rural areas. The study recommends that banking institution should extend their branch network to Growth Points and carry out humanistic financial inclusion campaigns to educate people living with visual impairment on the products they offer. Banking institutions should educate visually impaired people on how to use assistive devices to transact with banks. Government should cheap in and provide these devices, since visually impaired people do not afford.

The study indicated that the standard of living of visually impaired people were very poor. The study recommends that government, corporate community and Non-profit organisation should play a key role to alleviate the plight of these marginalised visually impaired people.There is need for social grants to visually impaired people in the rural areas. They should also be assisted to start income generating projects since visually impaired people were of the view that disability does not mean inability. They felt that they were supposed to be financially included as a means of improving their standard of living.

\section{REFERENCES}

Muromo, B. (2014). The place of the visually challenged in mainstream media: The Zimbabwean case. The Dyke. $8(1): 58-74$.

Munemo, T. (2015). Enhancement of access and inclusion of people with visual impairment in the electorate process in Zimbabwe. PhD in Special Needs. Harare: University of Zimbabwe.

Poisios, M. (2012). Mobile accessibility tools for the visual impaired. New York: Institute of Mathematics Science.

Ahmed, A. Y. (2015). Banks extends internet banking and mobile banking services for visually impaired customers. www.googlescholar.com (Accessed 06/03/2018).

Reserve Bank of Zimbabwe (2017). Customer protection framework. No.1-2017/BSD. www.google.com (Accessed 28/02/2018).

Navarismhan, N, et al. (2012). Making Mobile phones and services accessible for persons with disabilities. 
www.e-accessibilitytoolknit.org (Accessed 20/02/2018)

Omari, J. O. and Zachery, O. B. (2013). Investigating ATM system accessibility for people with visual impairments. Journal of Computer Engineering. 15(5):13-18

Pal, J. et al., (2017). Agency in assistive technology adoption: Visual impairment and smartphon use in Bangalore. USA:Derver Company.

American Report (2016). Regulations, risk and solutions for compliance. USA: AFB and Actuate Corporation

Lloyds Bank Report (2016). Additional needs: making everyday banking easier for customers. Britian: Lloyds bank

Bhuvana, M. and Vasantha, S. (2016). Drivers of financial inclusion to reach out poor. Arabian Journal of Business and Management review. 6(4): 35 -50

International Finance Corporation (2016). Financial Inclusion: Creating opportunity through financial services in South Asia. World Bank Group.

Joshi, P. D. (2011). Financial inclusion and Financial literacy. India: Bi OCED SEMINAR

Mago, S. and Chitokwindo, S. (2014). The impact of mobile banking on Financial inclusion in Zimbabwe: A case of Masvingo Province. Mediterranean Journal of Social Science. 5(9):221 - 230.

Mataruka, N. (2015). Financial inclusion in Zimbabwe Banking and microfinance sector. Harare: Reserve Bank

Morgan, J. P. and Pontines, V. (2014). Financial stability and Financial inclusion. Japan: Asian Development Bank Institute

Ndlovu, I. and Ndlovu, M. (2013). Mobile banking the future to rural financial inclusion: A case study of Zimbabwe. Journal of Humanities and Social Science. 9(4):70-75

Shah, P. and Dubhashi, M. (2015). Review paper on Financial Inclusion: The means of inclusive Growth. Chanakya International Journal of Business Research. 1(1):37-48

Sharma, A. and Kukreja, M. (2013). An analytical study: Relevance of financial inclusion for developing nations. Research invent: International Journal of Engineering and Science. 2(6):15-20 